\title{
Model vzdělávacího kurzu aplikovaných pohybových aktivit zaměřený pro pedagogické pracovníky v oblasti volného času
}

\section{Model of training course in adapter physical aktivity aimed for educional staff working in the field of leisure time}

\author{
Klára Šindelková, Ondřej Ješina \\ Fakulta tělesné kultury, Univerzita Palackého v Olomouci, \\ Česká republika
}

\section{Abstrakt:}

Cílem př́spěvku je představit model kurzu aplikovaných pohybových aktivit (APA) pro pedagogické pracovniky v oblasti volného času $(V C)$. Byl vytvořen a ověren pilotni model a dramaturgický rámec kurzu s využitím zážitkové pedagogiky včetně specifik zpětné vazby. Tohoto pilotniho ověreni se zúčastnilo 65 studentů oboru APA v prezenční i kombinované formě studia. Kidealizaci kurzu jsme došli pomoci ankety a cílené zpětné vazby realizované jako součást kurzů. V př́spěvku uvádíme hlavni doporučení pro praxi - návrh personálního obsazení vzdèlávacího kurzu, výběr vhodných aktivit pro rozvoj specifických kompetencí, nastavení vhodné fyzické i psychické zátěže apod. Výsledkem naši práce je vypracováni modelì vzdélávacích programů ve dvou variantách - tř́denní (víkendový) a sedmidenni (týdenní). Kurz je zaměren na pedagogické pracovniky, instruktory zotavovacích pobytových akci a ostatní profese zabývajicí se praci s osobami se speciálními potrebami v kontextu pohybových programů ve V̌́. 


\section{Abstract:}

The aim of the paper is to present the model of the course of adapted physical activity (APA) for educational staff working in the field of leisure time (LT). It was created and validated a pilot model and script editing the course framework with the use of experiential pedagogy, including specifics of the feedback. This pilot verification was attended by $65 \mathrm{stu}$ dents of department of APA in attendance as well as the combined form of studies. The idealization of the course we use surveys and targeted feedback implemented as part of the courses. In the paper, we present the main recommendations for the practice of staffing - proposal for a training course, the selection of appropriate activities for the development of specific competencies, setting up appropriate physical and mental burden, etc. The result of our work is to develop models of educational programs in two versions - a three-day (weekend) and 7-day (weekly). The course is aimed at teachers, instructors, fit! ness activities events and other professions engaged in working with persons with special needs in the context of programmes in LT.

Klíčová slova: zážitková pedagogika, vzdělávání, outdoorové aktivity, kompetence.

Key words: experience education, education, outdoor activities, competences.

Příspěvek vznikl jako součást projektu Centra podpory integrace CZ.1.07/1.2.00/08.0117 podporovaného ESF a rozpočtem $\check{C} R$.

\section{ÚVOD}

Rozvoj aplikovaných pohybových aktivit ve vztahu k outdoorovým aktivitám není zdaleka tak řešeným tématem jako integrace do školní tělesné výchovy a přitom pedagog volného času specialista v oblasti 
Model of training course in adapter physical aktivity aimed for educional staff working in the field of leisure time Model vzdělávacího kurzu aplikovaných pohybových aktivit zaměřený pro pedagogické pracovníky v oblasti volného času

APA (či instruktor APA) by měl hrát velmi důležitou roli v hledání kvality života lidí se speciálními vzdělávacími potřebami. $Z$ tohoto důvodu jsme se zaměřili u studenti̊ aplikovaných pohybových aktivit na jejich rozvoj a vzdělávání v oblasti volnočasových aktivit a volnočasových aktivit v prírodě.

Neuman et al. (2000) definuje výchovu v prrírodě jako výchovu o prŕrodě, poskytující znalosti a vědomosti se zdůrazněním zkušenostního a prožitkového př́stupu, dále ji charakterizuje jako výchovu mající akcent ekologický, hledající soulad a porozumění individua s prrírodou. Proto je výchova $\mathrm{v}$ prrírodě prrínosem pro cílovou skupinu, se kterou pracujeme. Je důležité, aby studenti daným programem sami prošli a dále mohli předávat a rozvíjet získané zkušenosti pro práci s lidmi se speciálními vzdělávacími potřebami. Hošek (2000) uvádí, že pohybová aktivita obohacuje člověka nejen fyzicky, ale obohacuje i jeho prožitky, proto je pro nás spojení fyzické aktivity, výchovy v prrírodě a prožívání východiskem pro využívání prvků zážitkové pedagogiky.

„Od nepamèti lidstvo hledalo cesty, jak se vyrovnávat s omezením vlastního života, jak tvorit a zanechávat po sobě stopy pro budouci generace. Je k tomu nutná inspirace a povzbuzení. To je cílem výchovy, která se neomezuje jen na předávání poznatků či dovedností, ale usiluje o obecnou nápravu věci lidských, o hledání smyslu života i o vytváření každodenního životního stylu, který by byl ve shodě se zvolenými a uznanými hodnotami. " (Holec, 1994, p. 18).

Zpětná vazba je $\mathrm{v}$ pedagogice, $\mathrm{v}$ procesu učení, důležitou fází, vnímáme ji jako hodnocení. Slavík (1999) zdůrazňuje, že hodnocení nedělitelně patří $\mathrm{k}$ hodnotám, $\mathrm{k}$ jejich objevování, vyzdvihování, potvrzování ale i kritizování a zpochybňování. Slavík (1999); uvádí, že „Hodnocení je díky své konativní funkci nutným průvodcem činnosti. Zabezpečuje výběr nejvhodnějši cesty, která má vést k uskutečněni hodnoty neboli k dosažení cíle (p. 21). "Proto jsme se rozhodli, že zpětná vazba na kurz pro nás bude důležitým východiskem. Fungujeme na principu zkušenostního učení, je pro nás velmi důležitá zpětná vazba účastníků abychom i my mohli program a přístup co nejideálněji přizpůsobovat 
skupině. Označení pro model učení, vycházejícího z vlastního prožitku, zážitku. Učení ze zkušenosti (zkušenostní učení) je starý koncept, který využíval už Aristoteles. Jde o jednoduchý princip, kdy proběhne akce (zážitek, zkušenost) my se za ní poohlédneme, tedy shrneme co se dělo, celou situaci zhodnotíme: co jsme dělali dobře, co se nedařilo a na závěr ze zjištění sestavíme plán pro př́šše (jak budeme postupovat $\mathrm{v}$ další, podobné akci).

Naším cílem je představit model vzdělávacího kurzu aplikovaných pohybových aktivit (APA) pro pedagogické pracovníky v oblasti volného času (VČ) a názor účastníků kurzu na vybrané realizované aktivity.

\section{HLAVNÍ ČÁST}

\section{METODIKA VÝZKUMNÉHO ŠETŘENÍ}

\section{Popis výzkumného souboru}

Cílovou skupinou kurzu bylo 29 studentů prezenčního i kombinovaného studia prvního ročníku aplikovaných pohybových aktivit. Mezi studenty bylo 10 mužů a 19 žen. Průměrný věk byl 28 let. Kurzu se účastnili dva studenti s postižením. Žena s dětskou mozkovou obrnou (chodící, sportovní úroveň CP7) a muž paraplegik, využíval k pohybu ortopedický vozík. Tento muž kurz po druhém dni opustil z důvodu vážného onemocnění. Celkově na kurzu bylo 8 osob, které mají pracovní zkušenosti $\mathrm{v}$ domech dětí a mládeže nebo dalších organizacích zabývajících se volným časem pro osoby se speciálními potřebami.

Absolventi studijního oboru mohou hledat své uplatnění jako vychovatel se zaměřením na pohybové aktivity $\mathrm{v}$ domovech pro osoby se zdravotním postižením a dalších zařízeních (družiny, DDM apod.), realizátor, vedoucí a poradce pohybových programů běžných, integrovaných i separovaných pro populaci se speciálními potřebami (zdravotním postižením, zdravotním a sociálním znevýhodněním a jinými) Absolvent je kvalifikovaný pracovník s orientací na APA, který komplexně zajišt'uje nebo řídí výchovně vzdělávací a koordinační činnosti v oblasti využití volného času dětí, mládeže a dospělých se zdravotním postižením. 
Model of training course in adapter physical aktivity aimed for educional staff working in the field of leisure time Model vzdělávacího kurzu aplikovaných pohybových aktivit zaměřený pro pedagogické pracovníky v oblasti volného času

\section{Metodika}

Vzhledem k cílové skupině a možnostem jejich profesního zaměření jsme na základě analýzy literatury sestavovali dramaturgii kurzu a prostředky pro evaluaci dle principů zážitkové pedagogiky na míru. Důležité bylo zastoupení teoretických i fyzických programů s různým typem náročnosti, organizačně zaměřené programy a vzdělávací programy pro práci se skupinou v outdoorových aktivitách. Dramaturgie kurzu nám napomáhá ve vyváženosti psychické a fyzické náročnosti programů a drží nám dynamiku a pružnost kurzu. Dramaturgie se připravuje do scénáře, který vytváří realizační tým. Pro nás byly hlavními složkami kurzu na jejichž základě se utvářeli programy a aktivity tyto bloky: zvyšování kompetencí studentů v práci se skupinou, práci s lidmi se speciálními vzdělávacími potřebami, tvorby programů pro osoby se SVP, seznámení se s různorodostí kompenzačních pomůcek, nabídnout studentům zásobník aktivit - rozcviček a energizerů pro budoucí praxi, vedení skupiny při cyklistických výletech a vodní turistice, posílení vlastního sebevědomí a pedagogické praxe. Metodu pro výzkum jsme potom použili dotazování, techniku ankety vlastní konstrukce (otevřené vs. uzavřené otázky). Anketou jsme zjišt’ovali, jak účastníci vnímají jednotlivé aktivity, evaluaci i celý kurz.

\section{Popis realizace projektu}

$\mathrm{Na}$ přípravě kurzu se podílel celý instruktorský tým zastoupen 3 muži - působících jako učitelé na UP v Olomouci, odborníci v oblasti práce $\mathrm{s}$ lidmi se speciálními vzdělávacími potřebami, práce se skupinou, outdoorové aktivity, vedení a vzdělávání lidí a 3 ženami zabývající se oblastí cykloturistiky, práce se skupinou, zážitkovou pedagogikou, zpětnou vazbou atd. Výsledkem naší práce byl scénář kurzu. Ten podrobně popisuje aktivity, které na kurzu proběhly. 


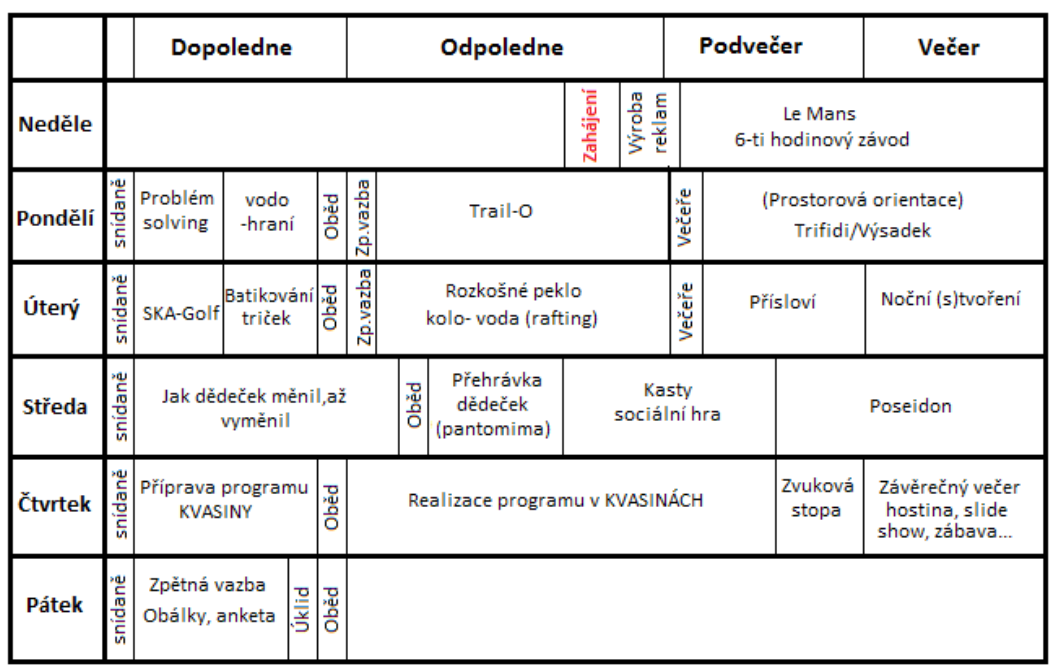

Obr. 2: Scénář kurzu

Nyní si podrobně představíme scénář kurzu a stručný popis aktivit.

Neděle:

Zahájení: představení instruktorského týmu, představení zdravotníka kurzu, seznámení se s chodem kurzu, nadstavení pravidel a chodu střediska.

Výroba reklamy: doplňující program kreativního charakteru využit $\mathrm{v}$ následujícím programu, účastníci zde mohli získat inspiraci pro tvorbu atmosféry delšího programu Le-Mans.

Le Mans: součástí aktivity Le-Mans byla autoškola, která se na jiných integračních kurzech zařazuje jako samostatný program. Cílem tohoto programu je seznámit účastníky s mobilitou na mechanickém vozíku, jízdu vpřed, vzad, otočky, dopomoc vozíčkáři a základní oprava.

Le Mans: 6hodinový fyzicky i psychicky náročný program motivovaný 24hodinovým závodem formule 1 Le-Mans. Cílem aktivity je 
Model of training course in adapter physical aktivity aimed for educional staff working in the field of leisure time Model vzdělávacího kurzu aplikovaných pohybových aktivit zaměřený pro pedagogické pracovníky v oblasti volného času

fyzická náročnost pro vnímání reality, ocitl jsem se na kurzu a ted' tu pár dní budu, odprostění od všedních starostí a nadstavení dynamiky kurzu. Po stránce psychické jde o strategii týmu, motivaci a výdrž. Na integrovaném kurzu získává tato aktivita druhý rozměr ve využívání kompenzačních pomůcek. Na dráhu, kterou musí závodníci absolvovat, jsou vysíláni se zavázanýma očima a vodičem, na tandem kole, vyzkouší sijízdu na terénním i klasickém handbiku a v neposlední řadě absolvují celý okruh na mechanickém vozíku.

Pondělí:

Problém - solving: aktivity zaměřené na týmovou spolupráci a na řešení daného úkolu (problému) ve skupině. Stává se složen cca ze tř́i různých zadání, vzestupně od nejlehčích po nejsložitější.

Vodohraní: se stává jako předaktivita vodní turistice kdy s pomocí raftu a pádel procházejí skupiny menšími hříčkami, ale zároveň se již seznamují s materiálem a aktivitami které mohou dále provádět se svými účastníky v okolí bazénu.

Zpětná vazba: velký papír pocitů a barev: tento papír měl taktéž sloužit k hodnocení aktivit, bezprostředně hned po aktivitě. Uvedli jsme, jak bude princip fungovat. Každá aktivita má svou baru, po aktivitě bude možnost zanechat stopu tam, kde jste se při aktivitě cítil. Papír je rozdělen do čtyř kvadrantů: psychicky i fyzicky jsem se cítil výborně, byl jsem psychicky i fyzicky ne dně, psychicky jsem se cítil dobře, ale fyzicky jsem už nemohl, fyzicky jsem na tom byl dobře, ale psychicky jsem byl vyčerpán.

Trail-O: Orientační závod spojen s šifrou a úkoly řešící problematiku z oblasti aplikovaných pohybových aktivit. Původně měl být zaměřen jako cyklistický závod, plán byl pozměněn na jeden mechanický vozík do skupiny.

Trifidi: psychicky náročná večerní aktivita, kdy jsou účastníci po celou dobu se zavázanýma očima provázení náročným a členitým terénem. Simulace zrakového postižení, vybočení ze zóny komfortu, skupinová snaha o zachránění skupiny a navrácení zraku. 


\section{Úterý:}

Ska-golf: ranní energetická zábavná aktivita směřována především pro rozhýbání a jako zásobník malých hř́iček.

Batika: další ze způsobu aktivit, které mohou využít pro práci s klienty. Z naší strany pro účastníky upraveno tak, že ten co se dotýká materiálu má zavázané oči... ostatní ze skupiny ho navádějí k postupu. Rozvoj komunikace a spolupráce.

\section{Zpětná vazba}

Rozkošné peklo: program skládající se z malého cyklistického zábavného slalomu, většího teoretického výkladu s praktickou ukázkou od výměny duše na kole až po vedení organizované skupiny v terénu. Dále se sama skupina rozdělila na menší podskupiny a řídila si výlet $\mathrm{k}$ vodní nádrži Rozkoš. Tam se seznámili se základy vodní turistiky na raftu, způsob ovládání raftu, rozložení posádky, první pomoc a záchrana a ukončovalo se závodem družstev v obratnosti na raftu.

Př́ísloví: po fyzicky náročných aktivitách program zaměřený převážně na představivost a znalost českých rčení a přísloví. Program řešící také skupinovou spolupráci a nabízí se do zásobníku aktivit.

Noční stvoření: kreativně divadelní noční představení, které si účastníci sami tvořili podle zadání.

\section{Středa:}

Jak dědeček měnil, až vyměnil: socializačně komunikační hra, kdy se účastníci vydají na pout' se sirkou (v jejich př́ípadě batikovaným trikem) a mají se vrátit s co nejoriginálnější úlovkem, cílem je potkávat se s lidmi, komunikovat s nimi, vnímat jejich reakce, zájem a nezájem, sdílet ve skupině.

Př̀hrávka dědeček: pantomima - tento program jsme zařazovali jako lehkou zpětnovazební techniku, kdy účastníci sehrávkou pantomimy předváděli příběh, který po cestě prožili.

Kasty - sociální hra: psychicky náročná aktivita se zaměřovala na vlastní vnímání se v sociálních skupinách v životě, kde jsou a kde by si přáli být. Každá skupina byla omezená na určitý počet zájemců - proto 
Model of training course in adapter physical aktivity aimed for educional staff working in the field of leisure time Model vzdělávacího kurzu aplikovaných pohybových aktivit zaměřený pro pedagogické pracovníky v oblasti volného času

převažoval-li počet uchazečů o danou sociální skupinu, ve které by chtěli žít, na základě obhajoby, proč by tem měli a neměli být ostatní účastníci, hlasovali jestli si obhájí post $\mathrm{v}$ dané skupině nebo budou automaticky zařazeni do nižší tř́ídy.

Poseidon: byl aktivitou navazující na kasty. Jak z něj účastníci vyšli tak byli rozděleni na lodi Poseidon s krycím jménem Queen Marry. Dle tříd byl na lodi zajištěn luxus a strava, zároveň na lodi probíhá zábava do chvíle, než se spustí siréna s hlášení o potápějící se lodi. Všechny tř̌́dy se musejí evakuovat s předností první třídy a snažit se o záchranu. Ta není bohužel možná pro všechny, proto někteří z posádky zůstávají uvězněni v těle potápějící se lodi. Další členové posádky zůstávají uvězněni na náročné trase $\mathrm{s}$ lanovými a př́rodními překážkami. Aktivita je náročná psychicky i fyzicky, ukazuje možnosti sociálních tříd a následné uvědomení si života. Následující den by ze zásady měla proběhnout zpětná vazba řízena člověkem s psychologickým zaměřením.

\section{Čtvrtek:}

Příprava programu Kvasiny: další program se opírá už o vlastní tvorbu a práci s lidmi se skupinou. Účastníkům je zadán projekt pro tvorbu zábavného a soutěžního odpoledne pro klienty s mentálním postižením. Na skupině je rozdělení si rolí, kdo co bude zastávat, sestavení programu, starají se o hudbu, odměny, dopravu... vše je v jejich rukou, z naší strany jde o předání zodpovědnosti na ně samé.

Realizace programu Kvasiny: odjezde a realizace celého naplánovaného programu.

Zvuková stopa - závěrečný večer na Pavlátce: závěrečný večer doprovázela př́jemná atmosféra $\mathrm{z}$ povedeného programu, naposled účastníci usedli na Pavlátové louce a se zavázanýma očima jim byl puštěn zvukový trailer z toho, čím si v průběhu kurzu prošli, jak se vyvíjela jejich cesta na kurzu až po realizaci programu v kvasinkách, co prožívali, jak se cítil - zvuková stopa byla mířena také jako zpětnovazební technika jim samým - tedy poohlédnutí za tím, co jsem zde prožil. Po rozvázání očí na účastníky čekal společný raut a zábava. 
Pátek: Zpětná vazba, obálky, anketa.

\section{VÝSLEDKY A DISKUSE}

Zde se již budeme zabývat výsledky z ankety, stupni hodnocení jednotlivých aktivit a celkovou pohledem na kurzu.

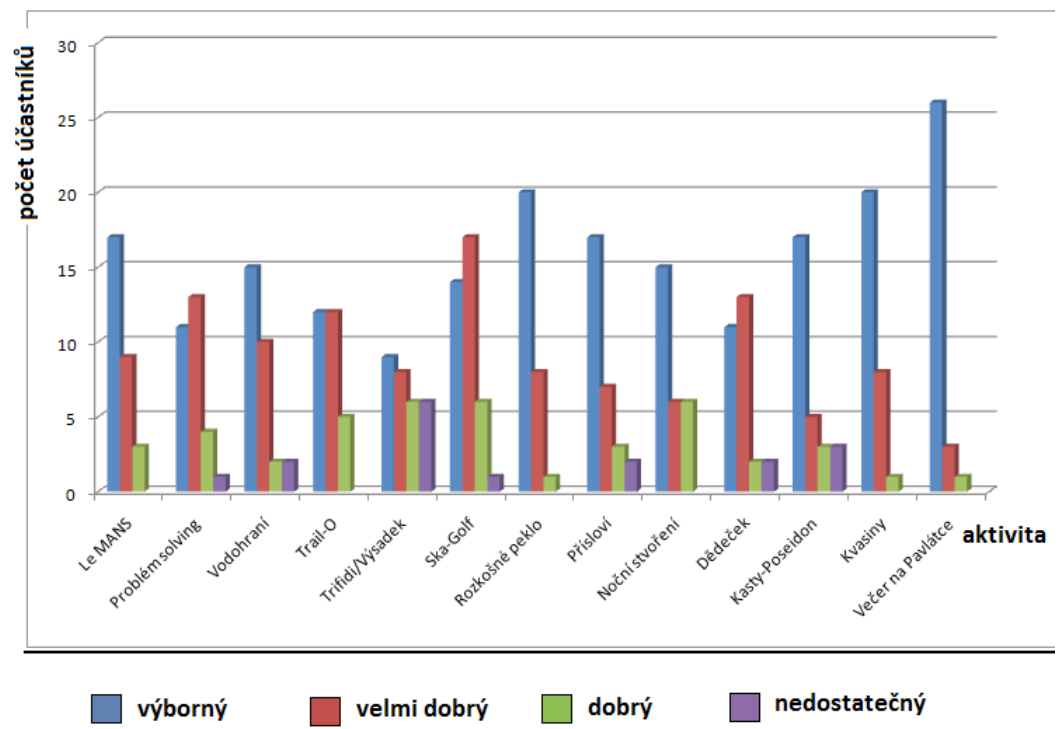

Obr. 3: Výsledky ankety - vnímání jednotlivých aktivit kurzu

Dle výše uvedeného grafu vidíme závěrečný večer na Pavlátově louce jako nejúspěšnější aktivitu, musíme ale podotknout, že nešlo o cílený program jako o závěrečné rozloučení. Velmi milým překvapením bylo pro mě, stejně jako pro zbytek týmu, že hned další velmi kladně hodnocenou aktivitou byla právě návštěva a program pro klienty z Kvasin. Stejně tak se líbil i povinně vsunutý blok Rozkošné peklo (kola a voda) i „orvávača“ Le Mans. Aktivity bez jediného negativního odhodnoce- 
ní: Kvasiny, Večer na pavlátově louce, Noční stvoření, Trail-O a také již zmíněné Rozkošné peklo a Le Mans.

Jedinou aktivitou, která byla hodnocená více, jak pěti účastníky nedostatečně byli Trifidi, převážně skrz jejich nezarámovaný konec. I tak se ale našli účastníci, kteří právě Trifidy vnímali jako nejlepší program na kurzu.

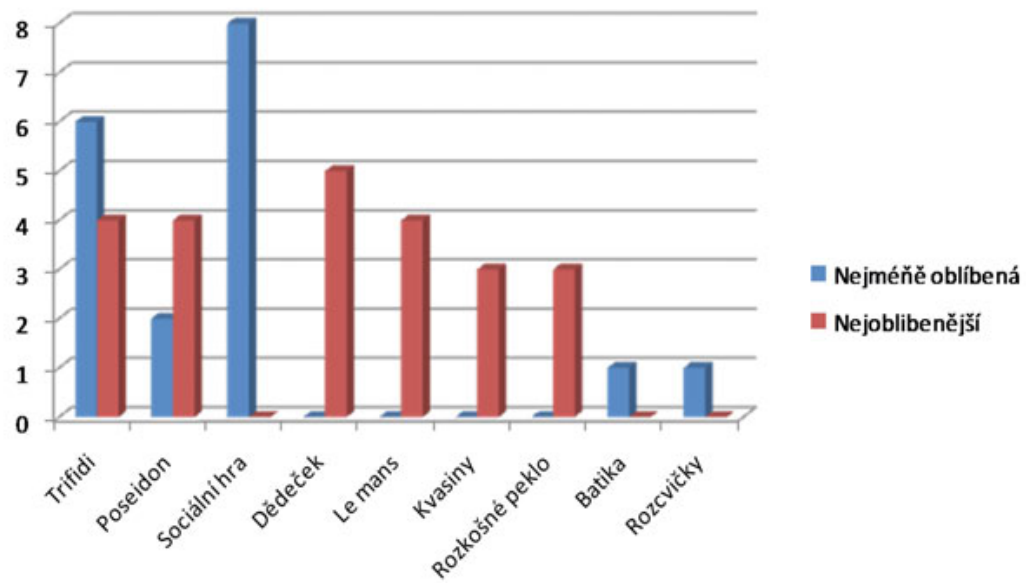

Obr. 4: Výsledky ankety - nejoblibenější a nejméně oblibené aktivity, porovnání

Na výše uvedeném obrázku 3. je klíčové k povšimnutí, převážně u hry Poseidon a Trifidi, jak rozdílně dokázali účastníci dané aktivity vnímat. Komplexně pro $6 \mathrm{z}$ nich byla hra Trifidi nejméně povedenou aktivitou, ale pro čtyři účastníky se stali nejlepší aktivitou kurzu. Podobně je tomu i u aktivity Poseidon. Dva účastníci jej hodnotí jako hru, která je nejméně oslovila, za to čtyři účastníci z ní byly nadšení.

Celkový program kurzu vnímali účastníci dle grafu: 


\section{Celokové hodnocení kurzu}

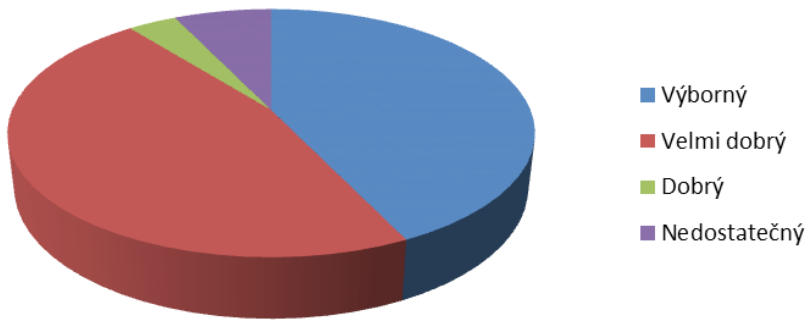

Obr. 5: Výsledky ankety - celkové hodnoceni kurzu

\section{ZÁV̌̌R}

Jedním z mnoha hesel zakladatelky APA v ČR a hlavní postavy historie této kinantropologické disciplíny (prof. Válkové) je „bí flexibl“, a právě pružnost $\mathrm{v}$ rozhodování a vysoká míra adaptace (modifikace) realizovaných činností je průvodním jevem obdobných kurzů. Právě proto jsme se nezaměřovali pouze na deskripci aktivit a obsahu, ale v závěru jsem pracovala převážně s názory účastníků, které jsem zpracovala $\mathrm{z}$ ankety a dalších forem zpětné vazby. Zajímavě působí rozpor názoru na nejlepší a nejméně povedené aktivity. Zde aktivity, které někteří účastníci hodnotí, jako nejméně povedené další účastníci hodnotí jako ty nejlepší na kurzu. Proto mají výsledky z grafů, pouze informativní charakter. Důležitější jsou pro nás zjištění rozlišnost názorů naší cílové skupiny. Nevidíme jako klíčové zjišt'ování libých či nelibých pocitů, ale v příštím šetření bychom se více zaměřily na přínos z hlediska osobnostního rozvoje, prínos z oblasti práce se skupinou a přinejmenším přínos pro vlastní praxi. Ve zpracovávání ankety a vytváření doporučení jsme nejvíce pracovali s odpověd'mi na otevřené otázky, jejichž výsledky poté využila v doporučení pro praxi. Na základě výsledků ankety jsme na budoucí rok realizovali velmi podobný kurz, jehož se účastnilo 36 studentů, který měl velmi shodující se výsledky. Do budoucna pracujeme s vizí pořádat 
Model of training course in adapter physical aktivity aimed for educional staff working in the field of leisure time Model vzdělávacího kurzu aplikovaných pohybových aktivit zaměřený pro pedagogické pracovníky v oblasti volného času

kurzy pro širokou veřejnost, kde bychom rádi pracovali s nestejnou délkou kurzu pro jiné cílové skupiny. Rádi bychom šírili aplikované pohybové aktivity v týdenním kurzu mezi pedagogické pracovníky, kteří pracují s intaktní populací a ještě nevědí, jak obohacující může být pro ně i pro skupinu pořádat akce otevřené i lidem se SVP. Druhý běh kurzů, kratší forma by byla zaměřena po pedagogické pracovníky, kteří mají zkušenosti s lidmi se SVP, ale chtějí si rozšíriit působení v oblast outdoorových aktivit neboli aktivit $\mathrm{v}$ prírodě.

\section{Doporučení pro praxi}

Velmi pozitivně se nám osvědčilo pestré vyvážení týmu tedy personálního obsazení a oblasti, kterými se daní odborníci zabývají. Těmito oblastmi byli: aplikované pohybové aktivity a pohybové aktivity v př́rodě, modifikace a úprava daných aktivit, cyklistický instruktor - průvodce, instruktor vodní turistiky - záchranář vodní turistiky, tvorba programu, práce s dramaturgií, motivací, zážitková pedagogika, zpětná vazba, odborník z oblasti pedagogiky a psychologie, práce se skupinou. $\mathrm{Na}$ základě výpovědi účastníků i vlastního uvážení velmi pozitivně shledáváme, kdyby se na kurz objevil at' už v účastnické pozici nebo instruktorské člověk se SVP. Dále pozitivně a přínosem může působit host pracující s určitou specifickou cílovou skupinou nebo netradičním programem. Do skupiny hostů může být pozvána také osobnost z oblasti APA - významný sportovec, někdo kdo překonal sám sebe, nebo dokázal v životě něco netradičního.

Jako další oblast, která je velmi důležitá pro praxi je výběr vhodných aktivit pro rozvoj specifických kompetencí, využívání velkého množství dostupných kompenzačních pomůcek (popřípadě i nějaké zapůjčit) ukázat účastníkům jak široké jsou možnosti a s čím vším mohou v průběhu své praxe pracovat. Nadále podporovat sportovně-pedagogické kompetence: cyklistický výlet a jeho organizace, základy vodní turistiky, lezecké dovednosti a práce $\mathrm{s}$ lanem, orientace a pohyb v prŕrodě. To vše je třeba zapojit vyváženě do dramaturgie a scénáře kurzu kde pracujeme s fyzickým a psychickým rozpoložením účastníků, zařazujeme programy na základě toho, kam chceme účastníky směřovat a co jim má kurz přinést. 
Důležitou součástí dramaturgie je také aktivní konání, zatím jsme se jim zabývali v rámci tvorby programu pro lidi s mentálním postižením, nic nemění na tom, že takových aktivit nemůže být více. Př́nosem pro lidi, kteří budou do budoucna pracovat na kurzech i s lidmi se SVP, může být program s názvem bezbariérové středisko, účastníci budou mít možnost sami z materiálu vytvořit plošinky a rampy, vodící linie atd. pro zlepšení mobility lidí se SVP. Dalším aktivním konáním může být modifikace náhodně vybrané hry at' pro osoby se zrakovým, tělesným nebo sluchovým postižením, vnímám to jako aktivitu, kdy účastníci nebudou už jen pasivně přijímat, ale budou nad věcí přemýšlet a tvořit.

\section{LITERATURA}

Holec, O. et al. (1994). Instruktorský slabikář. Brno: Prázdninová škola Lipnice.

Hošek, V. (2000). Sport zlepšuje kvalitu života. Psychologie dnes, 4.

Neuman, J. (2011). Dobrodružné cvičení a hry v prírodě. Praha: Portál.

Slavík, J. (1999). Hodnocení v současné škole. Východiska a nové metody pro praxi. Praha: Portál.

\section{KONTAKT:}

Bc. Klára Šindelková, SindelkovaKlara@gmail.com 